Paedagogia Christiana

2/30 (2012) - ISSN 1505-6872

Joanna Falkowska*

Toruń

\title{
Pierwiastek religijny w wychowaniu narodowym. Postulaty okresu autonomii galicyjskiej
}

\section{Uwagi wstępne}

Uzyskanie przez Galicję autonomii było ważnym impulsem do walki społeczeństwa polskiego na rzecz odbudowy rodzimej nauki, kultury i oświaty. Sytuacja Polaków w zaborze austriackim, która była najkorzystniejsza spośród trzech zaborów, wyzwoliła w światłej części społeczeństwa (ludziach nauki i kultury) tego okresu doniosłe inicjatywy. Zrodziły się też wówczas ważne idee dotyczące rodzimej oświaty. Był to niezwykły czas kształtowania się instytucji autonomicznych, wydawania ustaw i rozporządzeń dotyczących życia społeczno-politycznego, oświatowego i naukowego, a także okres rozwijającej się myśli pedagogicznej. Pojawiały się również coraz to nowe publikacje dotyczące propozycji reform oświatowych a także rozwoju szkolnictwa oraz wychowania młodzieży. To także na tym obszarze powstały projekty wychowania narodowego, które częściowo mogły być realizowane w ówczesnej szkole. W myśl owych koncepcji, przy pomocy odpowiednich metod i środków planowano kształtować młodych ludzi na patriotów gotowych poświęcić wszystko dla dobra narodu.

Galicyjscy myśliciele doby autonomicznej byli zdania, że w proponowanym przez nich programie edukacji narodowej nie mogło zabraknąć treści

* Dr Joanna Falkowska jest adiunktem na Wydziale Nauk Pedagogicznych Uniwersytetu Mikołaja Kopernika w Toruniu. 
religijnych. W wypowiedziach i pracach autorów tego okresu dotyczących religii odnajdziemy nie tylko to, jak i czego uczyć, ale także jaką postawę zgodną z zasadami religijnymi prezentować, a zatem jak żyć. Analiza publikacji omawianych twórców pozwala stwierdzić, że religii została przypisana doniosła rola. Autorom projektów edukacyjnych nie chodziło jednak wyłącznie o przekazywanie wiedzy religijnej, choć i to było istotne, ale również o rozbudzanie w narodzie, a przede wszystkim w młodych ludziach, uczuć religijnych, aktywnego przeżywania wyznawanych wartości i bogatego życia wewnętrznego. Kwestia religii i wiary była niezwykle znacząca w kształtowaniu postaw patriotycznych i budowaniu tożsamości narodowej. Wśród poruszanych problemów dostrzec można takie zagadnienia, jak: zaangażowanie $\mathrm{w}$ przeżywanie uczuć religijnych, życie w zgodzie z doktryną Kościoła, znaczenie czynów świadczących o postawie człowieka oraz problem nauki religii. Piszący na ten temat byli przekonani, że dla charakteru i moralności kształtującego się młodego człowieka nauka i wychowanie zgodnie z doktryną Kościoła katolickiego było sprawą priorytetową.

\section{Edukacja religijna}

Józef Dietl, rektor Uniwersytetu Jagiellońskiego i obrońca polskiej szkoły, w pracy pod tytułem O reformie szkót krajowych stwierdzał: „Jawną przeto jest rzeczą że Kościół i szkoła, te dwie najdzielniejsze potęgi moralne, ściśle łączyć się musza, jeżeli wychowanie młodego pokolenia ma być zbawienne i pożyteczne" . Był zwolennikiem nauki religii w szkole, gdyż ma ona, jego zdaniem, wychowawcze wartości. Przestrzegał natomiast, że kształcenie młodzieży, nawet w niższych szkołach ludowych, nie może się ograniczać do samej tylko nauki religii². W jego opinii część odpowiedzialności za naukę religii i moralności spoczywać powinna nie tylko na duchowieństwie, ale także na rodzicach. W domu rodzinnym, zdaniem autora, zaczynać się winno pierwsze spotkanie młodego człowieka z religią. J. Dietl twierdził, że między Kościołem i szkołą nie ma stosunku zależności, a jedynie stosunek wzajemnej pomocy, a nauka religii stanowi podstawę moralnego wychowania człowieka. Podkreślał, że to szkoła ma wykształcić w młodym człowieku uczucia religijne, mówiąc: „Wychować w dziecku człowieka, wykształcić jego umysł, uszlachetnić jego usposobienie, wzbudzić w nim uczucia religijne i moralne $[. .$.$] oto w krótkich słowach jest wielkie, ale trudne zadanie$

\footnotetext{
${ }^{1}$ J. Dietl, O reformie szkół krajowych, Kraków 1865, s. 12.

2 Tamże, s. 14.
} 
szkoły ludowej"3. Stwierdzał również, że jeśli wychowanie opierać się będzie na wartościach religijnych, ma szansę odnieść sukces. Uzasadniał swoją tezę następująco: „Wychowanie będzie ludzkie, jeżeli opierać się będzie na zasadach religijno-moralnych; obywatelskie, jeżeli żywiąc miłość kraju i uwzględniając przyszły zawód uczących się dzieci, udzielać będzie tych wiadomości, które im najniezbędniej są potrzebne"4.

Inny myśliciel tego okresu, Bronisław Trzaskowski, naukę religii uważał za „duszę” wszelkiego wychowania. W swoim dziele pod tytułem Zarys organizacji szkół niższych odniósł się do tej kwestii tymi słowami: „Ona to objawia człowiekowi odwieczne prawdy boskie, ona odsłania przed duszą jego ostateczny cel życia, ona wskazuje mu jego stosunek do twórcy i świata i wynikające stąd obowiązki względem Boga, siebie i bliźniego; przez co łagodzi obyczaje jego, podnosi umysł, uszlachetnia serce i przysposabia skutecznie do wszelkiego dalszego udoskonalenia"s. Widział więc w nauce religii szereg doniosłych czynników, bez których człowiek nie jest w stanie sam odpowiedzieć na pytanie, skąd przychodzi i dokąd zmierza. Ogromną odpowiedzialność za to, w jakiej formie nauka ta zostanie uczniom podana, nakładał na duchowieństwo. Krytyce poddawał dotychczasowy sposób prezentowania podopiecznym wiedzy religijnej, piętnując przede wszystkim nauczanie pamięciowe czy powtarzanie definicji. Twierdził, że nauka ta nie da się ujać ani przedstawić za pomocą żadnego systemu prezentowanego w książkach. Powinna ona, zdaniem B. Trzaskowskiego, płynąć z serca i sumienia. Był także wyrazicielem poglądu, że to pobożna matka rozpoczyna ze swym dzieckiem naukę religii, i to od niej nauczyciel winien przejąć wiedzę, jak dalej tę naukę kontynuować. Apelował „nie udzielamy nauki religii w szkołach niższych tak, jak jej stosownie do jej istoty udzielać trzeba. Idzie zatem i to, że nauka ta tak mało wpływa na późniejsze życie uczniów"6. Trzeba więc, zdaniem autora, by nauka ta po pierwsze była udzielana nie tylko w ramach zajęć szkolnych, ale wszędzie tam, gdzie jest to możliwe. Po drugie natomiast, by nauczana była w sposób, który wywrze wpływ na całe życie wychowanków. Kierował więc swoje słowa do nauczycieli, aby podczas modlitwy szkolnej, jak również w czasie rozrywek, podczas nauki kościelnej i nauki świeckiej, w każdym czasie, słowie i czynie uczyć prawdziwie młodzież szkolną religii ${ }^{7}$. Podobne zalecenia proponował stosować podczas nauki historii biblijnej, tak aby uczniowie żywo reagowali na żywo-

\footnotetext{
3 Tamże, s. 9.

4 Tamże, s. 149.

5 B. Trzaskowski, Zarys organizacji szkół niższych, Lwów 1867, s. 23.

6 Tamże, s. 24.

7 Tamże, s. 25.
} 
ty świętych i starali się odnosić je do własnego życia. W ten tylko sposób, twierdził B. Trzaskowski, nauka religii i historii biblijnej trafia w serca młodych ludzi i ma głęboki sens.

O znaczeniu religii w wychowaniu mówił też Zygmunt Balicki. Podkreślał on ogromne znaczenie tak zwanego „uczucia religijnego”. Twierdził, że jest ono niezbędne dla prawidłowego ukształtowania człowieka. Nie chodziło mu z pewnością tylko o wierzenia teologiczne i kosmologiczne ${ }^{8}$. Znając stosunek do religii tamtego pokolenia, można stwierdzić za B. Grottem, iż chodziło o „pogłębione predyspozycje osoby ludzkiej do wytrwałego zaangażowania i przeżywania wyznawanych wartości niż o pozostawanie w pełnej zgodzie z doktryną Kościoła"9. Religia według Z. Balickiego nie powinna opierać się tylko na wierzeniach teologicznych, ale przede wszystkim na uczuciu religijnym. Był zdania, że „Życie ludzkie będzie zawsze duchowo ubogie, bezradne - nawet w swej bucie - i pozbawione kręosłupa moralnego, jeżeli mu nie przyświeca absolut uczuciowej harmonii, podparty najwyższą syntezą umysłowa, godzącą ze sobą wszystkie sprzeczności żywota. Religia daje nam to mocne przeświadczenie, że nie ma sił szkodliwych, że są tylko siły użyteczne, chociaż niekiedy źle nastawione"10. Religia to według niego coś, co daje młodemu człowiekowi jedność i harmonię wewnętrzna, chroni go także od poczucia, że wszystko jest względne. Tak rozumianą religię chciał z pewnością uczynić ważnym elementem wychowania narodowego.

Innego rodzaju uwagi na ten temat wygłaszał Euzebiusz Czerkawski. Zabierał on głos przede wszystkim w sprawie sposobu nauki religii. Taka nauka powinna uwzględniać, według niego, wykład historii biblijnej, ale zawierać też powinna obrazy z życia patriarchów i przywódców wybranego narodu, powoływanych do spełnienia jego misji. Tezę swą uzasadniał słowami, że „Z tego powodu biblijna historia tyle dla młodzieży ma powabu, a przy tym i tę korzyść, że szereg podawanych w niej obrazków stanowi zaokragloną do pewnej miary całość"11. Religię chciał zatem powiązać z nauką historii religii, widząc w takim rozwiązaniu wiele korzyści. Stwierdzał, że z jednej strony historia święta $\mathrm{z}$ dziedziny dziejów ludzkich jest bardzo korzystna dla rozwoju wychowanków, ponieważ thumaczy jego przeszłość i genezę moralną, a $z$ drugiej strony jest ona dopełnieniem wiedzy o prze-

${ }^{8}$ Z. Balicki, Zasady wychowania narodowego, Warszawa 1909, s. 13.

9 B. Grott, Zygmunt Balicki. Ideolog Narodowej Demokracji, Kraków 1995, s. 52.

10 Tamże, s. 153.

${ }^{11}$ E. Czerkawski, Rozprawy i wnioski komisyi powołanej w roku 1879 przez Galicyjska Radę Szkolnq Krajowq do zbadania sprawy reformy gimnazjów, Lwów 1882, s. 57. 
szłości, historii własnego kraju i własnego narodu ${ }^{12}$. W jego poglądach dominowały więc elementy religioznawstwa połączone z wiedzą o przeszłości narodu polskiego. W takim ujęciu, w opinii E. Czerkawskiego, nauczanie religii stanowi pewną całość i sprawia, że młodzież zapoznaje się także z faktami dziejowymi.

Nieco inny pogląd na wiarę i religię w życiu narodu prezentował w swoich projektach edukacyjnych Wincenty Lutosławski. Najpełniej o znaczeniu religii pisał on w pracy pod tytułem Religia $w \dot{z}$ yciu narodowem ${ }^{13}$. To wierze przypisywał on zasadniczą rolę, a rozumiał ją jako ,przekonanie, którego przesłanek w zupełności nie obejmujemy świadomością, we wszystkich stosunkach ludzkich tak wyraźnie przeważa nad wiedzą, że niema nadziei, byśmy się mogli bez niej obejść nawet przy urzeczywistnieniu najśmielszych oczekiwań co do rozwoju myśli ludzkiej i naukowych badań"14. Zdaniem piszącego, to także drogowskaz wskazujący właściwe ścieżki, dający odpowiedzi na wszystkie pytania w każdej dziedzinie życia.

W wypowiedziach na ten temat stwierdzał:

Wiara więc oświeca drogę wiedzy, zawsze ją wyprzedzając, i Mickiewicz trafnie określił istotny stosunek wiary do wiedzy, gdy powiedział, że rozum bez wiary byłby niewidomy, bo dopiero promień wiary, którą Niebo wznieca, zapala gromy rozumu i oświeca jego zwierciadła. [...] Tylko wiara daje odpowiedzi na te pytania, i na wiele innych pytań w zakresie życia politycznego i społecznego, przy czym wiara nie tylko wyprzedza badania rozumu, lecz sięga często tam, gdzie on nigdy nie będzie mógł za nią podążyć ${ }^{15}$.

W. Lutosławski głosił, że to za sprawą wiary przyjmujemy dane przekonania bez ich rozumowego uzasadnienia, dlatego też sądził, że taka wiara odgrywa ogromną rolę w życiu społecznym i politycznym. Był także pewien, że aby żyć i działać, nie można karmić ducha,,sieczką udowodnionych pewników”, trzeba mieć bowiem jakieś ideały, wzywające zarówno do ryzyka, jak i ofiary ${ }^{16}$. Wskazywał, że społeczeństwo bez wiary nieuchronnie stałoby się też społeczeństwem bez czci i wiary, a żadna ludzka wiedza nie wystarczy dla najważniejszych decyzji życia narodowego. Wszystkie nasze działania i plany, w myśl jego słów, polegają właśnie na wierze ${ }^{17}$. W. Lutosławski był

\footnotetext{
12 Tamże.

${ }_{13}$ W. Lutosławski, Religia w życiu narodowem, Warszawa 1909.

14 Tamże, s 7.

15 Tamże, s. 11.

16 Tamże.

17 Tamże, s. 12.
} 
też zwolennikiem teorii, że wiara dla tych, którży ją szczerze i naturalnie wyznają, może być potężnym źródłem sił, a zatem pomaga stać się dobrym obywatelem. Wyraził też pogląd, że „ten, kto wierzy, że ciagle jest otoczony duchami potężnymi i życzliwymi, będzie czuł wielki przypływ sił własnych, a będzie się czuł moralnie skrępowanym wobec tych świadków i przyjaciół, gdyby miał pokusę popełnić jakich czyn nieszlachetny"18. Dobry katolik więc, w opinii W. Lutosławskiego, znajdzie w swej wierze pobudki, aby zostać zacnym obywatelem. Równie ważnym według niego elementem wiary jest przekonanie, że po każdym upadku można zacząć nowe życie, otrzymawszy rozgrzeszenie za najgorszą nawet przeszłość, lecz wyłącznie wtedy, kiedy postanowi się poprawę ${ }^{19}$. Widział więc w wierze i religii szansę na podniesienie narodu z upadku moralnego. Wysunął hipotezę, że wiara katolicka przez surowe swe wymagania wzmaga poczucie odpowiedzialności moralnej u swych wyznawców i zabezpiecza ich w znacznej mierze przed nagłymi wybrykami. Podkreślał też, że to właśnie Polacy ze swego usposobienia są do nich bardzo skłonni. Posiadają też, według niego, wrodzoną lekkomyślność, która wymaga hamulców moralnych ${ }^{20}$. W swoich rozważanich dotyczących religii i wiary poruszył także ważną kwestię nauczania młodzieży przez nauczycieli innej wiary i narodowości, co jednoznacznie krytykuje i widzi w tych działaniach niekorzystne skutki dla edukacji religijnej. W sumie doszedł do wniosku, że:

Nasza młodzież była do niedawna wychowywana całkowicie przez nauczycieli nie tylko innej wiary, lecz także innej narodowości, traktujących tę młodzież z podejrzliwością i niechęcią, co nawzajem podobne uczucia płodzi. Młodzież w ten sposób musiała tracić naturalne i pożądane poważanie dla swych nauczycieli, a taki stosunek podkopał nie tylko indywidualną powagę nauczycieli, ale wszelką powagę w ogóle. Gdy autorytet nauczycieli upada, pociaga to za sobą upadek wszelkiego autorytetu - uczniowie przejmują się nihilizmem i ufają nadal tylko sobie, aż wreszcie i w siebie wiarę traca, a wtedy nic im już nie pozostaje. Takie były skutki szkoły wynaradawiającej i służącej politycznym celom, z takich szkół przez długi szereg lat wychodzili ludzie niezdolni do żadnej wiary, lekceważący tradycję i pomiatający religią, a przytem nie zdający sobie sprawy z tego, że ta utrata wiary zubożyła ich ducha i moralnie ich wynarodowiła ${ }^{21}$.

\footnotetext{
18 Tamże, s. 23.

19 Tamże, s. 23-24.

20 Tamże, s. 25.

21 Tamże, s. 41-42.
} 
Podkreślał zatem konieczność uregulowania tej kwestii, ukazując daleko idące szkodliwe i wrogie konsekwencje dla polskiej młodzieży. Podsumowując jego poglądy na problem religii i wiary, także społecznej i politycznej, należy stwierdzić, że widział w nich siłę i szansę dla narodu polskiego. Był przekonany, że wszelka szczera, a przede wszystkim głęboka wiara społeczna, polityczna czy religijna jest siłą twórczą. Wiedzie bowiem ona, jego zdaniem, do czynów. Potwierdzeniem tej tezy mogą być słowa W. Lutosławskiego, że „Majątek narodu polega nie tylko na zapasach wytworów materialnych, lecz i na sile oraz rozmaitości wierzeń, z których powoli wyrabia się coraz to więcej nieomylnych dogmatów"22.

Równie gorąco do zajęcia się sprawami religii i wiary zachęcał Stanisław Prus-Szczepanowski. Był przekonany, że gorąca wiara w tryumf dobrej sprawy jest istotną treścią religii. Dlatego też, według niego, wiara, jak i religia dowodów nie potrzebuje. Mawiał, że „Sercu szlachetnemu sama się narzuca, jako najprawdziwsza oczywistość. Sercu spaczonemu, zwatpiałemu i trwożliwemu żadne dowody nie wystarczą"23. Tak rozumiana wiara i religia powinna zdaniem autora obok trwałych zasad ewangelii zastąpić w pedagogice polskiej „strupieszały scholastycyzm”, którym ówcześnie karmiono młode umysły, a który, jak to określi, ,daleko częściej wywołuje niestrawność, aniżeli wiarę"24. Wiara jest jednak, według niego, martwa bez uczynków, bez poparcia jej działaniem. Należy zatem być „dzielnym w dobrej sprawie”. S. Prus-Szczepanowski przeciwstawia czyny niedołęstwu Polaków i wskazuje owo niedołęstwo jako największy grzech narodowy. „Podnietą zaś uniwersalna, i wiecznie tak samo podniecającą uczucia narodowe, jak przemysł i handel, mający swe podstawy w pragnieniu szczęścia materialnego, apostołuje sprawie kosmopolityzmu - jest uczucie religijne, z dusz ludzkich wydobywając najistotniejsze pierwiastki kultury narodowej, tak, że w całym przebiegu historii religia okazuje się wskrzesicielką narodów"25.

Podobnie jak E. Czerkawski, także i S. Prus-Szczepanowski widział łączność religii z historią narodu. Sądził, że „Nigdzie kierunek religijny nie pojawia się wybitniej, jak w polskim pojmowaniu historii własnego narodu" ${ }^{26}$. Był również zdania, że żaden inny naród nie posiada takiego wartościowego szeregu wielkich i znaczących postaci, w których się uosabia sumienie narodu, począwszy od św. Stanisława biskupa, kardynała Oleśnickiego i ks. Skargi, do ks. Marka, do Mickiewicza i Krasińskiego. Wyrażał też

\footnotetext{
22 Tamże, s. 48.

23 S. Prus-Szczepanowski, Aforyzmy o wychowaniu, Monachium 1946, s. 211.

24 Tamże, s. 213.

25 Tenże, O polskich tradycjach $w$ wychowaniu, Lwów 1912, s. 11.

26 Tamże, s. 252.
} 
pogląd, że u żadnego innego narodu (z wyjątkiem starożytnego narodu izraelickiego) religia nie łączy się tak ściśle jak w narodzie polskim z historią. Zaprezentował tezę, że tak, jak naród izraelski, tak i polski w każdym zdarzeniu widzi „palec Boży”, karę za grzechy lub błogosławieństwo za dobre uczynki. Był więc również wyrazicielem poglądu, że religia ściśle wiąże się z przeszłością narodu polskiego. Mówiąc o sumieniu narodu i przywołując wybitne postaci z historii Polski, chciał zwrócić uwagę na znaczenie religii, zwłaszcza dla Polaków i ich egzystencji.

\section{Miejsce Kościoła w edukacji narodowej}

Mówiąc o pierwiastku religijnym w wychowaniu narodowym, trzeba też powiedzieć o ważnej roli Kościoła katolickiego i jego przedstawicielach w polskiej szkole. O znaczeniu Kościoła wypowiadano się zwykle, mając na uwadze relację Kościół-państwo-społeczeństwo. Należy zatem zapytać, jaką rolę Kościoła widziano w wychowaniu narodu polskiego? Czy przewidywano i oczekiwano konkretnych działan Kościoła względem szkoły? Czy oddziaływanie Kościoła było ważne w społeczeństwie, szukającym na nowo swojej tożsamości? Wydaje się, że dominującym poglądem wśród twórców poruszających tę kwestię było to, iż Kościół i szkoła mają do zrealizowania szereg ważnych dla narodu zadań. Niektórzy sądzili także, że to Kościół i szkoła są najważniejszymi elementami życia społecznego, a co za tym idzie, mają do zrealizowania niezwykle istotne zadania ${ }^{27}$.

Wspomniany już rektor Uniwersytetu Jagiellońskiego J. Dietl zauważał, że „Kościół jest wprawdzie instytucją, lecz instytucją boską, i jako taka przynależną autonomię mieć musi”"28. Był więc zwolennikiem Kościoła w pełni autonomicznego, niezależnego od państwa. Sądził też, że Kościół i szkoła są to dwie, jak to określił, najsilniejsze potęgi duchowe w społeczeństwie. Pierwsza potęga - Kościół, ponieważ zaszczepia w człowieku przy pomocy religii pierwsze uczcucia moralne, zapoznaje go z właściwym przeznaczeniem, poucza o obowiązkach, jakie ma względnem Boga i bliźniego, wskazuje wyższą godność człowieka, objawia odwieczne prawdy boskie, niejako wznosi go ponad poziom wszystkich innych żywych istot ziemskich, uobyczaja, uszlachetnia i przyspasabia do dalszego udoskonalenia ${ }^{29}$.

27 Tematyka ta pojawiła się w następujących pracach: J. Dietl, dz. cyt.; W. Seredyński, Pedagogia polska w zarysie, Lwów 1868; B. Trzaskowski, dz. cyt.; Z. Balicki, Zasady; S. PrusSzczepanowski, Idea polska wobec prądów kosmopolitycznych, „Słowo Polskie” (1897); tenże, O polskich; W. Lutosławski, dz. cyt.

28 J. Dietl, dz. cyt., s. 11.

${ }^{29}$ Tamże, s. 12. 
Kościół w myśl jego przekonań wychowuje człowieka, jest więc pierwszą i zarazem najsilniejszą potęgą wychowawczą. Szkoła natomiast, jako druga potega wychowawcza, zwykle oświeca i naucza, a tym samym wychowuje. Jednak, co podkreśla stanowczo J. Dietl, bez pomocy religii nauka szkolna byłaby pozbawiona najskuteczniejszego działacza pedagogicznego ${ }^{30}$. Jasno głosił też, że „Jawną przeto jest rzeczą, że Kościół i szkoła, te dwie najdzielniejsze potęgi moralne, ściśle łączyć się muszą jeżeli wychowanie młodego pokolenia ma być zbawienne i pożyteczne. Połączenie zaś to musi być tym ściślejsze, czym niższe są szkoły, najściślejsze przeto w szkołach ludowych. $\mathrm{W}$ tych bowiem szkołach, szczupłe wiadomości dzieciom udzielane [...] mało tylko przyczynić się mogą do wychowania duchowego"31. J. Dietl zauważył również doniosłość tego połączenia właśnie ze względu na to, że na szkole niższej więsza część ludności kończyła swoją edukację. Była to więc jedyna okazja, by poprzez naukę religii wychować człowieka. W szkołach wyższych natomiast, według niego, młodzież potrafi już samodzielnie nad sobą pracować i uzupełniać swoje dotychczasowe wychowanie w tym zakresie. Wyraził pogląd, że nieporozumieniem byłoby, gdyby Kościół chciał lub musiał się usunąć ze szkoły, a zwłaszcza ze szkoły ludowej ${ }^{32}$. Tam bowiem, zdaniem J. Dietla, to kapłan jest głównym i jedynym przewodnikiem wychowania ludowego. Pomimo tego więc, że widział dla Kościoła szereg ważnych zadań, nie stawiał go na najwyższej pozycji. Potwierdzeniem tej tezy mogą być słowa: „Z tego wszystkiego co powiedzieliśmy, nie wynika jednak bynajmniej, żeby Kościół górował nad szkołą [...] Wynika przeciwnie tylko to, żeby Kościół łącznie ze szkołą zajmował się wychowaniem młodego pokolenia" ${ }^{33}$. Opowiadał się więc jednoznacznie za owocnym współdziałaniem szkoły i Kościoła bez wskazywania, który z tych dwóch elementów ważnych w wychowaniu młodego człowieka ma decydujący wpływ. W swoich przemyśleniach zawarł także pogląd, że Kościoł ma obowiązek decydować o kształcie nauki religii w szkołach. Czyni to jednak, zdaniem J. Dietla, na mocy danej mu przez rząd. Tak oto skomentował stan ówczesnej nauki religii: ,Jeżeli przeto w dzisiejszym składzie szkół Kościół pewny i przeważny wywiera wpływ co do nauki religii lub co do nadzoru nad szkołami ludowymi: nie czyni on to z prawa mu przynależnego i przyznanego lecz raczej z obowiązku nań włożonego, czyni to, nie jako właściwa i uprawniona do tego zwierzchność, lecz jako zobowiąznay i powołany do tego posłannik,

\footnotetext{
30 Tamże

31 Tamże, s. 13.

32 Tamże.

33 Tamże.
} 
czyli delegat rządowy"34. Był przekonany, że taki właśnie jest stosunek szkoły do Kościoła we wszystkich niemal cywilizowanych krajach.

Ponadto, w żadnym państwie, według niego, Kościół nie jest wyłącznym zwierzchnikiem szkoły, ponieważ w tak zwanych radach szkolnych zasiadają zarówno reprezentanci rządu, jak i osoby duchowne oraz fachowcy. Dodatkowo zaprezentował tezę, że kształcenie młodzieży nawet w najniższych szkołach ludowych nie może się ograniczać do samej tylko nauki religii, ale także i to, że nadzór nad tymi szkołami nie może a przynajmniej nie powinien być powierzony wyłącznie Kościołowi. $Z$ rozważań tych wynika, że nauka religii i moralności, według J. Dietla, nie powinna być wyłącznym prawem lub obowiązkiem duchowieństwa ${ }^{35}$. $Z$ jego słów wypływa przesłanie, że to w rodzinie rozpoczynać się powinna ta nauka.

W prezentowanej przez siebie teorii na temat roli Kościoła w życiu narodu dobitnie podkreślał, że: „Nie masz między kościołem i szkołą żadnego stosunku zależności, lecz zachodzi między nimi stosunek wzajemnej pomocy. Kościół nie może się obejść bez szkoły bo za jej pomocą najpewniej i najskuteczniej szerzy swoją naukę. Szkoła nie może się obejść bez Kościoła, a mianowicie bez nauki religii, która stanowi podstawę moralnego wychowania człowieka" ${ }^{36}$. Wyraźnie widoczne w jego poglądach jest akcentowanie takiego właśnie spojrzenia na powinności Kościoła wobec szkoły i społeczeństwa. Pisał, że szkoła i Kościół to dwie najważniejsze instytucje w społeczeństwie, które dążą do wspólnego celu. Stwierdzał też, że do tego celu powinny dążyć nie tylko wspólnie, ale też zgodnie i życzliwie. Relacja ta, jak wynika z jego słów, powinna się wyzbyć zazdrości, jakichkolwiek roszczeń czy przekroczeń swoich granic. Tylko wtedy, jak zapewniał, spełnią one należycie swoją misję, a więc kształcąc i wychowując społeczności światłych i pożytecznych obywateli ${ }^{37}$.

Co na temat znaczenia wiary i Kościoła w życiu narodu sądził Władysław Seredyński? W swych publikacjach zabierał on głos w sprawie wychowania chrześcijańskiego. Mówiąc o systemie wychowania wygłosił tezę: ,że drogą w tej mierze najprostszą i najpewniejszą - jest droga chrześcijaństwa" ${ }^{38}$. Nie wypowiadał dosłownie swojego stanowiska w sprawie zadań i miejsca Kościoła, był jednak zdania, że ważnym w życiu i wychowaniu młodych ludzi jest wychowanie chrześcijańskie, którego Kościół jest niewątpliwie ważną częścią. W wychowaniu tym cenił skromność, swoistą niepewność, rozbu-

\footnotetext{
34 Tamże, s. 14.

35 Tamże.

36 Tamże, s. 14-15.

37 Tamże, s. 15.

38 W. Seredyński, dz. cyt., s. 32.
} 
dzanie ufności. Był przekonany, że „Już skromność chrześcijańskiego wychowania tkwiąca w tym, że nie wszystko obiecuje z matematyczną pewnością, że nie na samym filozoficznym rozumowaniu się opiera, ale uwzględnia to, co jest konieczne ludzkim, i chce dokonać tylko tyle i ile się da; ta skromność porywa za sobą każdego myślącego człowieka i budzi ufność w swą rzetelnmość i istotną wartość" ${ }^{39}$. Był więc zwolennikiem wychowania w duchu chrześcijańskim, dostrzegał jego pozytywne aspekty, nie zajmował natomiast jednoznacznego stanowiska w sprawie miejsca Kościoła w społeczeństwie.

W jaki sposób do tej kwestii odnosił się B. Trzaskowski? W publikacji pod tytułem Zarys organizacji szkót niższych, pisząc o koniecznej autonimii tych szkół, stwierdzał, że „Uwolnić więc należy szkoły niższe naprzód od wyłącznego wpływu i nadzoru władz kościelnych"40. W jego opinii do zadań Kościoła powinno należeć wpływanie na wychowanie religijne i moralne, jednak nie może mieć miejsca sytuacja, w której to Kościół decyduje o wszystkich sprawach dotyczących szkół ludowych. Zdaniem B. Trzaskowskiego nauka religii stanowić winna główną i najważniejszą podstawę „wychowania początkowego”. Zauważył również, że Kościołowi należy się pewien patronat i dogląd szkół niższych, jednak tylko w pewnych granicach, które wyznacza właśnie nauka religii i wychowanie moralne. Był wyrazicielem poglądu, że nie można się zgadzać na wyłączny nadzór i zarząd szkoł niższych przez organy władzy kościelnej ${ }^{41}$. Wśród powodów takiego stanowiska wymieniał po pierwsze specyficzne kwalifikacje, których Kościołowi i jego reprezentantom brak, a które są wymagane w kwestii kierownictwa nad szkołami niższymi. Duchowieństwo funkcjonujące w ,innym zawodzie" takich umiejętności, jego zdaniem, nie posiada. Stał na stanowisku, że Kościół nie dysponuje też doświadczeniem w tym zakresie. Po drugie, jak pisał, ,prawo kościoła do górowania na szkołami nawet niższymi w obecnym stanie rzeczy w żaden sposób udowodnić się nie da"42. Był więc reprezentantem stanowiska, w myśl którego Kościół z pewnością ma wiele zadań do wykonania, na przykład dozór w sprawie nauki religii i wychowania moralnego. Jednak w tym miejscu jego rola powinna się skończyć, gdyż brak jego przedstawicielom odpowiednich umiejętności.

Czy Kościół ma rzeczywiście jakąś istotną rolę w wychowaniu zastanawiał się także Z. Balicki. W swoim tekście pod tytułem Kształcenie charakteru, chcąc podkreślić porządane cechy przedstawicieli Kościoła, głosił, że

\footnotetext{
39 Tamże, s. 33.

${ }^{40}$ B. Trzaskowski, dz. cyt., s. 6.

${ }^{41}$ Tamże.

42 Tamże.
} 
„ksiądz lub oficer zawsze musi wiedzieć jak ma postąpić, nie wolno mu się ani wahać, ani ulegać wpływom, ani iść za popędem swoich uczuć lub nastrojów chwili" "43. Można sądzić, że oczekiwał od reprezentatnów Kościoła jasno określonej, niezahwianej moralnie postawy. Był też sympatykiem nauki religii, gdyż, według niego, religia właśnie daje duszy ludzkiej, a zwłąszcza duszy młodzieńczej, jedność i harmonię wewnętrzną, a także odkrywa przed nią życie duchowe. Z. Balicki zauważył też, że religia w pewien sposób chroni młodego człowieka od poczucia, że wszystko jest względne, znikome, przemijające i skończone ${ }^{44}$. Podkreślił również, że wszystkie działania podejmowane przez Kościół „powinny łączyć się organicznie z działalnością społeczną" ${ }^{45}$. Był więc także zwolennikiem pewnego współdziałania na linii Kościół-szkoła-społeczeństwo. W poprawnym funkjonowaniu tej relacji widział siłę i możliowści dla całego społeczeństwa.

Jak Kościół i jego zadania jawiły się S. Prusowi-Szczepanowskiemu? Widział on także, podobnie jak inni myśliciele, pewien program współdziałania na polu nauki i wychowania pomiędzy wszystkimi czynnikami, które funkcjonują w społeczeństwie, to znaczy między szkołą, w której działają odpowiednio przygotowani nauczyciele, Kościołem, który powinien stać na straży sumienia, oraz rodziną. Był zwolennikiem poglądu, że „Polska była i jest narodem Katolickim" ${ }^{46}$. Wysoko cenił działalność i twórczość narodowych pisarzy i poetów w „oparciu o życie Kościoła”. Był zdania, że wnieśli oni bez wątpienia wiele jeśli idzie o pojmowanie ojczyzny jako świętości. Zaprezentował myśl, że „Objawienie narodowe polskie - objawienie Mickiewicza, Krasińskiego, Słowackiego, Cieszkowskiego - wniosło do kościoła powszechnego ideę Ojczyzny jako świętości, na równi ze świętościami dawniej uznawanymi” ${ }^{47}$. Dodawał jednocześnie, że „naród polski słusznie łączy wyobrażenie religijne ze zbawieniem swej Ojczyzny ziemskiej i ze zwycięstwem sprawiedliwości Bożej w stosunkach narodowych i społecznych"48. Polacy, według niego, to naród głęboko katolicki, przekonany o nadejściu zbawienia. W jego opinii, Kościół winien częściej i głośniej propagować konieczność zdobywania wiedzy, poznawania prawdy, bez względu na okoliczności. W swojej Idei Polskiej proponował: „Kościół powszechny, gdyby do dogmatu piękna, bohaterstwa i patriotyzmu mógł dołączyć jeszcze

${ }^{43}$ Z. Balicki, Ksztatcenie charakteru, „Przegląd Narodowy” 10 (1912), s. 570.

${ }^{44}$ Tenże, Zasady, s. 154.

${ }^{45}$ A. Dawidowicz, Zygmunt Balicki (1858-1916). Działacz i teoretyk polskiego nacjonalizmu, Kraków 2006, s. 242.

${ }^{46}$ S. Prus-Szczepanowski, Idea, s. 264.

47 Tamże, s. 270.

48 Tamże. 
dogmat o wolności ducha, o świętości prawdy i wiedzy, o naczelnym obowiązku nieustraszonego poszukiwania jej, na przekór wszelkim tyraniom i wszelkim przemocom, to by zaprawdę stał się niezwyciężonym i wszystkie daremnie by się przeciwko niemu wysilały"49. Dostrzegał, że w ówczesnej sytuacji takiej postawy było Kościołowi zdecydowanie brak, na niekorzyść społeczeństwa. Ubolewał także nad bierną jego postawą, brakiem uświadamiania sobie ducha czasów, które wymagają innego spojrzenia i innych działań. Zastanawiał się też, dlaczego Kościół, jak to określił urzędowy i oficjalny, rzadko zdobywa się na uchwycenie ,żywych prądów czasu”. Stąd, jak wynika z jego słów, pewna nieporadność Kościoła w krytycznych chwilach. Chcąc zilustrować tę tezę przywołał postawę biskupów i księży wobec ruchów ludowców ${ }^{50}$. Ponadto podkreślał, że pewien marazm i niedołężność Kościoła jest zjawiskiem cyklicznym, które jest obecne w jego działalności. Potwierdzeniem tej myśli niech będą słowa: „Zresztą ospałość Kościoła urzędowego jest zjawiskiem, które się ciagle w historii powtarza" ${ }^{51}$. S. Prus-Szczepanowski krytykował bierną postawę Kościoła mówiąc, iż szanuje kontemplację, ale w odpowiednim czasie. W sytuacji walki uważał ją za lekkomyślność. Z pewnością dlatego też pozostawił na uboczu całą teoretyczną i kontemplacyjną stronę religii, a szukał sprężyn działania. Bo to właśnie działanie, jego zdaniem, a nie rozumowanie rozstrzyga o losach świata i narodów ${ }^{52}$. Powołując się na głos A. Mickiewicza w tej sprawie, poruszał aspekt spekulacji i teoretyzowania, zamiast realizacji i działania. Podkreślał, że „Nauka wydaje plon, staje się żywotna, dopiero w chwili, w której człowiek jej prawdę odkryje na nowo w sercu swoim. [...] Dlatego wiara żywi się przykładem, spełnieniem, świadczeniem, a nie rozumowaniem i nauką"53. Był więc zwolennikiem działania, nie teoretyzowania, aktywności na miarę nieprzeciętnych czasów.

Z drugiej jednak strony S. Prus-Szczepanowski uważał, że naród polski w pewnych sytuacjach skłonny jest do czynu religijnego. Mówił, że specyficzną cechą każdego Polaka jest stawanie z łatwością na najwyższym poziomie uczucia religijnego ${ }^{54}$. Wymaga to jednak, według niego, specyficznego traktowania spraw ważnych, rozbudzenia w narodzie postaw prowadzących do chęci zmian. Był przekonany, że trzeba „Polakowi pokazać to, co jest wielkie, wspaniałe i szlachetne, a on od razu bez argumentacji czuje,

\footnotetext{
49 Tamże.

50 Tamże, s. 271.

51 Tamże.

52 Tamże, s. 273.

53 Tamże, s. 274-275.

${ }^{54}$ Tenże, $O$ polskich, s. 251.
} 
że to jest właściwą ojczyzną jego ducha, że to są jego przyrodzone właściwości”'s5.

Co na ten temat sądził autor pracy pod tytułem Religia $w$ życiu narodowym, W. Lutosławski? Po pierwsze był wyrazicielem poglądu, że wiele w sprawach wiary, religii, roli Kościoła zależy od postawy jego przedstawicieli. Drugim ważnym dla niego czynnikiem było kultywowanie obrzędów religijnych, które niosą za sobą pewne wartości i zachowania. Innym istotnym, według niego, elementem był sposób funkcjonowania Kościoła. Wyrażał więc pogląd, że „Związki osób jednej wiary prowadzą do wyrażenia jej nie tylko w mowach i pismach, ale także we wspólnych obrządkach - i tu tkwi początek Kościoła i kapłaństwa. Kapłani są stróżami wszelkiego wyrazu tej wspólnej wiary, którą wyznają, i pełnicielami obrządków przez nią wytworzonych" ${ }^{56}$. Podkreślał rolę księży jako stróżów ważnych dla katolicyzmu i jego obrzędów. W jego opinii: „Naród - państwo - Kościół - to najzwyklejsze i najwięcej rozpowszechnione łączniki ludzi jednej wiary narodowej, politycznej lub religijnej. Czasem naród tworzy narodowe państwo, a państwo to ma swoją państwową religię lub Kościół narodowy”57. Był także przekonany o potrzebie określenia stosunku religii do narodowości i państwowości oraz wskazania, czy istnienie w danym państwie Kościoła jest potrzebne, pożądane i usprawiedliwione. Jego zdaniem „Ideałem Kościoła katolickiego, czyli powszechnego, była od początku śmiała nadzieja zjednoczenia wszystkich ludzi dobrej woli na całej ziemi, połączenia ich jednością wiary i niewidzialnymi węzłami przynależności ze społeczeństwem"58. Zadawał też pytanie, czy gorliwy katolik przez to, że jest katolikiem i że się uważa za członka pewnego związku, będzie przez tę wiarę hamowany w swoich dążeniach narodowych? Na tak postawione pytanie odpowiadał: „Pytajmy tylko o to, czy taka wiara doda mu sił w życiu narodowym, czy wzmoże jego chęci pełnienia obowiązków obywatelskich" ${ }^{59}$. Wygłosił też pogląd, że katolicy twierdza, że w dążeniach tych wiara im dopomaga, chociażby poprzez opiekę Świętych. Pogląd ten argumentował słowami: „Więc ten, kto wierzy, że ciągle jest otoczony duchami potężnymi i życzliwymi, będzie czuł wielki przypływ sił własnych, a będzie się czuł moralnie skrępowany wobec tych świadków i przyjaciół, gdyby miał pokusę popełnić jaki czyn nieszlachetny. Dobry katolik zatem znajdzie w swej wierze pobudki, aby zostać zacnym

\footnotetext{
55 Tamże.

56 W. Lutosławski, dz. cyt., s. 18.

57 Tamże.

58 Tamże, s. 19.

59 Tamże, s. 23.
} 
obywatelem"60. Wiedział on, że wiara może skłaniać do określonych, pożądanych postaw społecznych i bardzo to pochwalał. W. Lutosławski zauważał także, że Kościół w Polsce brał udział w najdonioślejszych momentach historii narodu. Był wyrazicielem poglądu, że zwycięstwo w ważnych dla narodu sprawach można zawdzięczać właśnie Kościołowi. Ilustracją tego założenia może być przekonanie W. Lutosławskiego, że do wielu czynów na przestrzeni dziejów trzeba było wiary, którą zawdzięczamy właśnie Kościołowi. Dodatkowo doceniał również udział duchowieństwa katolickiego w życiu narodowym, który, jak podkreślał, był tak znaczny, jak w żadnym innym narodzie katolickim. Działo się tak między innymi w czasach wielkich ruchów narodowych w kraju, jak określał to W. Lutosławski, począwszy od 3 maja. W wydarzeniach tych duchowieństwo zawsze brało bardzo gorliwy udział $^{61}$. Stawiał też pytanie, czy ten silny związek Kościoła z narodem polskim przetrwa pomimo kryzysu i upadku wiary? Jednoznacznie głosił, że „Odwrócenie się od Kościoła katolickiego bardzo wielu Polaków ostatniego pokolenia jest faktem niewątpliwym" ${ }^{2}$. Powodem, według niego, mógł być niski poziom umysłowy i moralny ówczesnego duchowieństwa, które nie potrafiło sprostać oczekiwaniom i potrzebom społeczeństwa. Jak więc widział sposób zaradzenia temu zjawisku? Otóż głosił pogląd, że błędem jest, że ,na wyższe studia duchowni muszą się udawać do Petersburga, wielkiego ogniska innej wiary, gdzie działa tyle wpływów osłabiających tę wiarę"63. Ubolewał nad tym, że najzdolniejsi księża nie są wysyłani na dalsze studia zagraniczne na katolickich uniwersytetach. Sądził, że tacy kapłani po latach pracy i zdobytych tam doświadczeniach przyczynić mogliby się do podniesienia poziomu umysłowego duchowieństwa w kraju. Krytykował również wpływ wynaradawiającego socjalizmu szerzonego przez Żydów. Zauważył jednak, że „,Ten wpływ podkopuje wiarę i łączność narodu z Kościołem, ale nie ma w sobie zadatków trwałości, gdyż wyrósł na obcym gruncie i jest zasadniczo przeciwny naszemu charakterowi narodowemu"64.

Niejako podsumowaniem jego poglądów na temat roli Kościoła w społeczeństwie mogą być słowa: ,W bilansie naszym narodowym stosunek do Kościoła jest tak poważną pozycją, że nie godzi się jej ignorować i lekceważyć. Więc kto się chce zająć polityką polską, ten powinien znajomość spraw Kościoła oraz treści nauczanej przezeń wiary uważać co najmniej za równie

\footnotetext{
60 Tamże.

61 Tamże, s. 27-28.

62 Tamże, s. 28.

63 Tamże, s. 41.

64 Tamże, s. 49.
} 
ważny czynnik roztropnego przygotowania do politycznej działalności, jak znajomość ekonomii politycznej i prawa" ${ }^{65}$. Doszedł do wniosku, że nawet dla Polaków niewierzących Kościół jest sprzymierzeńcem. Sądził także, że naród wierzący i biorący żywy udział w życiu Kościoła przechodzi ciężkie próby. Bywa, że wiarę traci, lecz bywa i tak, że ją zyskuje i pogłębia. Zawsze jednak, jego zdaniem, Kościół winien być podpora, niezachwianą wartością, do której można się odwołać w każdej sytuacji. Wyrażał myśl, że: „Kościół katolicki głosi dogmaty nieomylne i zawsze te same od wieków, a nigdy nie przerwał ciagłości tradycji, która w nim łączy przeszłość z teraźniejszością. Ta stałość ma urok niezrównany dla ruchliwego Polaka, który przynajmniej w swej religii chce mieć siłę, tchnącą bezwzględnym spokojem"66.

\section{Uwagi końcowe}

Wśród wielu głosów na temat znaczenia Kościoła w życiu narodu i religii $\mathrm{w}$ wychowaniu młodych ludzi zdecydowanie przeważają postulaty, iż elementy te mają doniosłą rolę. Należy też, według wielu autorów piszących w okresie autonomii galicyjskiej, przyznać Kościołowi prawo do decydowania o kształcie nauki religii w szkołach oraz o wychowaniu moralnym. Ważną rolę Kościoła widziano także wśród warstw niższych, to jest głównie w szkołach ludowych. Tam bowiem młody człowiek ma czasem jedyną szansę zetknięcia się ze sprawami religii i wiary. Wielką odpowiedzialność pokładano także na przedstawicielach Kościoła, księżach, którzy mają wpływ na uczniów w szkole i poza nią. Stwierdzano, że powinni oni mieć gruntowne przygotowanie i odebrać wykształcenie na katolickich uniwersytetach, także za granicą. Należy powiedzieć, że także w przypadku relacji Kościół-szkoła-społeczeństwo ideałem byłoby, według większości twórców, współdziałanie. Kościół, wiara i nauka religii były w ujęciu przywoływanych myślicieli okresu autonomii galicyjskiej ważnymi elementami w procesie wychowania, zarówno młodzieży, jak i całego społeczeństwa polskiego, stojącego przed wielkimi wyzwaniami.

\footnotetext{
65 Tamże, s. 32.

66 Tamże, s. 37.
} 


\section{Religious Education in National Curriculum during the Period of Galician Autonomy \\ (Summary)}

Religious education held an important place in the proposed curriculum of national education in the second half of the 19th century and the beginning of the 20th century. In the statements and works of the thinkers of that period about religion, the important thing was not only how and what to teach but also what moral stance to adopt that would be in accordance with religious principles - therefore, how to live. The analysis of publications of these authors allows us to establish that religion played an important role. The aim was not only to share religious knowledge, although this too was important, but also to awaken in the nation, and mainly in the young people, the religious feelings and encourage them to actively practice their values and beliefs and experience a rich spiritual life. The issue of religion and faith played a significant role in the shaping of patriotic attitudes and the construction of national identity. Among the discussed problems, those regarded as the most important were involvement in the experience of religious feelings, life in accordance with the doctrine of the Church, the significance of a person's actions that reflect their moral stance, and the problem of religious education at schools. 